\title{
Methods for evaluating rated power of diesel-powered generator set
}

\begin{abstract}
Basic concepts for evaluating rated power of generator sets powered by combustion engines are presented in this article. A relation between parameters of the engine and the generator are shown. Recommendations contained in the standards and technical literature are systematized. The scheme and methodology for evaluating rated power of the generator set, based on laboratory research, are suggested. Also, the main problems which occurred during research have been highlighted. The differences between the values of rated power assumed in theoretical consideration and obtained during laboratory research for the sample unit, have been commented upon.
\end{abstract}

Key words: generator set, evaluation of rated power, power measurement

\section{Metody wyznaczania mocy znamionowej agregatu prądotwórczego napędzanego silnikiem spalinowym}

\author{
Przytoczono podstawowe pojęcia zwiazane z określaniem mocy agregatów prądotwórczych napędzanych silnikami \\ spalinowymi. Podano relacje obowiazujace pomiędzy parametrami silnika i pradnicy. Usystematyzowano wskazania \\ zawarte $w$ normach oraz literaturze fachowej. Zaproponowano schemat i metodyke wyznaczania mocy znamionowej \\ agregatu na podstawie badań laboratoryjnych. Zwrócono uwagę na kluczowe problemy praktycznego przeprowadza- \\ nia badań. Skomentowano różnice w wartościach mocy znamionowej wyznaczonych teoretycznie oraz praktycznie dla \\ przykladowego agregatu. \\ Słowa kluczowe: agregat prądotwórczy, wyznaczanie mocy znamionowej, pomiar mocy
}

\section{Introduction}

Rated power is one of the principal parameters of a generator set. Correct evaluation of this parameter by the producer properly determines the exploitation of the unit. The rated power definition should also be properly understood by users of generator sets, so that they can make a suitable choice of the specific needs and, consequently, ensure appropriate operational conditions for electrical energy receivers.

In practice, the method of evaluating rated power of the generator set is sometimes incorrect. The practical significance of this parameter is also misinterpreted. The purpose of this article is to analyze the methods of evaluating rated power of the generator set and general systematization of knowledge within this domain.

\section{Rated power of a generator set}

The concept of rated power of a generator set is defined in PN-ISO 8528-1 standard [1]. Depending on the unit destination, the rated power should be determined by one of the following definitions:

a) continuous power (COP) - this is the power which a generator set is able to provide continuously for an indefinite time within a year, except for breaks reserved for servicing,

b) prime power (PRP) - this is the highest power obtainable within the duration of varying power which may occur during an unlimited number of hours in a year,

c) limited time running power (LPT) - this is the highest power which a generator set is able to deliver in less than 500 hours per year, of which a maximum of 300 hours is a continuous work between specified breaks reserved for servicing.

\section{Wprowadzenie}

Moc znamionowa jest jednym z podstawowych parametrów agregatu prądotwórczego. Prawidłowe określenie tego parametru przez wytwórcę agregatu warunkuje jego poprawną eksploatację. Pojęcie mocy znamionowej powinno być również właściwie rozumiane przez odbiorcę urządzenia, tak by dokonał właściwego wyboru agregatu dla konkretnych potrzeb i w konsekwencji zapewnił odbiornikom energii elektrycznej właściwe warunki pracy.

W praktyce sposób wyznaczania i opisywania mocy znamionowej agregatu bywa niewłaściwy. Mylnie interpretowane jest także praktyczne znaczenie tego parametru. Niniejszy referat ma na celu przeanalizowanie stosowanych metod wyznaczania mocy znamionowej agregatów prądotwórczych oraz ogólne usystematyzowanie informacji w tym zakresie.

\section{Moc znamionowa agregatu prądotwórczego}

Pojęcie mocy znamionowej (inaczej nominalnej) agregatu prądotwórczego zdefiniowano w normie PN-ISO 8528-1 [4]. W zależności od przeznaczenia agregatu moc znamionową należy określić według jednej z poniższych definicji:

a) moc znamionowa trwała (continous power, COP) - jest to moc, którą zespół prądotwórczy jest w stanie dostarczyć w sposób ciągły przez nieograniczony czas w roku, pomiędzy określonymi przerwami przeznaczonymi na konserwację,

b) moc znamionowa szczytowa (prime power, PRP) - największa moc możliwa do uzyskania $\mathrm{w}$ ramach ciągu zmieniających się mocy, które mogą występować w czasie nieograniczonej liczby godzin w ciągu roku, 
According to standard [4], the rated power should be specified in units of active power (Watts) including the rated power factor. The standard also defines the concept of the engine's auxiliary power, which is intended only for regulation purposes, i.e. transient load conditions and sudden increase in load. Auxiliary power should not be considered as the electric power supplied to consumers, and the manufacturer should not include it in the parameters given to the client. It should not be stated on the nameplate or in the technical documentation. Additional power is required regardless of the way in which the rated power of a generator set has been defined.

Appropriate operation of a device depends on important parameters of its functioning. Acceptable ranges of some parameter values are specified directly in standards concerning a generator set, e.g. frequency and output voltage value. Other parameters result from the definition of the unit's rated power. Permissible limit in the rise of temperature of the generator windings is one of such parameters. During the evaluation of rated power the parameters related both to the generator and the combustion engine should be considered.

\section{Methods of evaluating rated power of a generator set}

Rated power of a generator set can be evaluated using one of the following methods:

a) theoretically, on the basis of generator set components catalogue data,

b) experimentally, on the basis of simplified measurement for resistive load,

c) experimentally, on the basis of full measurement for compound resistive-inductive load with rated power factor.

Standards allow to perform the simplified measurement when an adjustable compound load is unattainable. After completing the simplified measurements rated power is calculated based on the measurement results and the relationship of power and efficiency for different power factors [6].

In order to compare the methods mentioned above, rated power of a generator set was determined. The unit consisted of the following components:

a) combustion engine Hatz type 1D81C (maximum power $\mathrm{P}_{\mathrm{Sn}}=9.6 \mathrm{~kW}$ at $\left.3000 \mathrm{rpm}\right)$,

b) 3-phase generator GTS type DWG 8/5-EE (rated power $\mathrm{S}_{\mathrm{Pn}}=10 \mathrm{kVA}$ at $\cos \varphi=0.8$; generator efficiency $\eta_{\mathrm{Pn}(0.8)}=$ $=0.82$ at $\cos \varphi=0.8$ or $\eta_{\mathrm{Pn}(1)}=0.87$ at $\cos \varphi=1$ ).

The generator set was built in a box adapted for mounting under the railway passenger car. Due to the character of unit application the COP type rated power was considered.

\section{Evaluating rated power of a generator set based on catalogue data of its components}

Rated power of a generator set can be estimated based on catalogue data given by producers of electric generator and combustion engine. The active rated power of a generator $\mathrm{P}_{\mathrm{Pn}}$ should not be lower than the rated power of a whole generator set $\mathrm{P}_{\mathrm{An}}$. Rated power of the generator is usually quoted as apparent power $\mathrm{S}_{\mathrm{Pn}}$ (in VA) for power factor $\cos \varphi$ c) moc znamionowa ograniczona czasowo (limited time running power, LTP) - najwyższa moc, którą zespół prądotwórczy jest w stanie dostarczyć w czasie nieprzekraczającym 500 godzin rocznie, z czego najwięcej 300 godzin jest pracą ciągłą pomiędzy określonymi przerwami na prace konserwacyjne.

Zgodnie z normą [4] moc znamionowa powinna być określona w jednostkach mocy czynnej (watach, W) z podaniem znamionowego współczynnika mocy. Norma definiuje także pojęcie mocy dodatkowej silnika, która przeznaczona jest wyłącznie do celów regulacyjnych, tj. przejściowych stanów obciążenia i nagłych wzrostów obciążenia. Mocy dodatkowej nie należy rozważać jako mocy dostarczonej odbiorcy energii elektrycznej, a producent agregatu nie powinien uwzględniać jej wartości w parametrach podawanych do informacji kupującemu. Nie powinna ona znaleźć się na tabliczce znamionowej urządzenia, ani w dokumentacji techniczno-ruchowej. Moc dodatkowa jest wymagana niezależnie od tego, jak zdefiniowano moc znamionową agregatu.

Poprawna praca urządzenia zależy od istotnych parametrów jego funkcjonowania. Dopuszczalne zakresy wartości niektórych wielkości określone są bezpośrednio w normach dotyczących agregatów, np. częstotliwość i wartość napięcia wyjściowego. Inne parametry wynikają z definicji mocy znamionowej agregatu. Przykładem takiej wielkości jest dopuszczalny długotrwale przyrost temperatury uzwojeń generatora. Podczas wyznaczania mocy znamionowej należy wziąć pod uwagę parametry związane zarówno z generatorem, jak i z silnikiem spalinowym.

\section{Metody wyznaczania mocy znamionowej agregatu}

Moc znamionową agregatu prądotwórczego można wyznaczyć jedną z poniższych metod:

a) teoretycznie, na podstawie danych katalogowych elementów składowych agregatu,

b) doświadczalnie, na podstawie pomiarów uproszczonych wykonywanych dla rezystancyjnego obciążenia agregatu,

c) doświadczalnie, na podstawie pomiarów pełnych, tzn. dla obciążenia o znamionowym współczynniku mocy.

Po wykonaniu pomiarów uproszczonych, dopuszczalnych w sytuacji braku odpowiedniego zaplecza technicznego, moc znamionowa obliczana jest na podstawie wyników pomiarów oraz zależności mocy i sprawności dla różnych współczynników mocy [6].

W celu porównania wymienionych metod wyznaczono za ich pomocą moc znamionową agregatu prądotwórczego zestawionego z następujących elementów składowych:

a) silnika spalinowego Hatz typu 1D81C (moc rzeczywista $\mathrm{P}_{\mathrm{Sn}}=9,6 \mathrm{~kW}$ przy $\left.3000 \mathrm{obr} / \mathrm{min}\right)$;

b) prądnicy trójfazowej GTS typu DWG 8/5-EE (moc znamionowa $\mathrm{S}_{\mathrm{Pn}}=10 \mathrm{kVA}$ przy $\cos \varphi=0,8$; sprawność prądnicy $\eta_{\mathrm{Pn}(0,8)}=0,82 \operatorname{przy} \cos \varphi=0,8$ lub $\eta_{\mathrm{Pn}(1)}=0,87$ $\operatorname{przy} \cos \varphi=1)$.

Agregat zabudowany był w skrzyni przystosowanej do montażu pod pudłem wagonu kolejowego. Z uwagi na zastosowanie agregatu rozważana była moc znamionowa COP. 
$=0.8$ [2]. If the power of a generator set was to be defined with the same value of power factor, the following assumption should be made:

$$
\mathrm{P}_{\text {An }} \leq \mathrm{P}_{\mathrm{Pn}}=\mathrm{S}_{\mathrm{Pn}} \cdot \cos \varphi
$$

Electrical output power of a generator is reduced in relation to the mechanical power supplied to it due to the occurrence of losses in the electric machine. Mechanical power $\mathrm{P}_{\mathrm{Sn}}$ on combustion engine shaft (called real power), needed to achieve the assumed rated electrical output power, can be estimated using the known generator efficiency $\eta_{\mathrm{Pn}}$, assuming that the operating conditions are close to nominal ones. In addition, it is necessary to provide a so-called engine's auxiliary power [4], which is destined for controlling purposes in transient conditions. This power usually equals $10 \%$ of the rated power. These conditions are described by relationship:

$$
\mathrm{P}_{\mathrm{An}} \leq \frac{\eta_{\mathrm{Pn}} \mathrm{P}_{\mathrm{Sn}}}{1.1}
$$

The estimated rated power of a generator set $\mathrm{P}_{\text {An }}$ will be the lower of the values obtained by equation (1) and (2). Rated power of the considered generator set, estimated based on the parameters of the combustion engine and the generator, is limited by the power of the combustion engine, and equals $\mathrm{P}_{\mathrm{An}(\mathrm{T})}=7156 \mathrm{~W}$.

\section{Evaluating rated power of a generator set based on experimental research}

Catalogue data of generator set components, given for some assumed working conditions, can change after assembling the components into the complete set. The change may result from different cooling conditions caused by closing the components in a box and thermal interaction between the electric generator and the combustion engine. Real value of the generator set power may also be affected by the interaction between the controller of engine shaft angular velocity and the controller of electric generator excitation [3]. For these reasons experimental verification of rated power of a generator set is recommended.

Rated power of a generator set is determined by proper values of operational parameters which influences unit life-time, gas and electromagnetic emission, and operation of electric receivers. A typical limitation of the electrical generator power is maintenance of correct temperature of the windings [4]. Due to the durability of insulation of the generator windings, its temperature should not exceed the limit value. This value depends on the so-called class of insulation material. For example - for class $\mathrm{F}$ the allowed long-term temperature is $155^{\circ} \mathrm{C}$ [2]. The condition defined on this way is impractical due to the changing conditions of generator cooling and practical difficulties connected with determination of the absolute temperature value. For this reason, the PN-EN 60034-1 standard uses the technical term of permissible temperature increase, with the assumption that the ambient temperature does not exceed $40{ }^{\circ} \mathrm{C}$.

\section{Określanie mocy znamionowej agregatu na podstawie danych katalogowych jego elementów składowych}

Moc znamionową agregatu można oszacować na podstawie danych katalogowych podanych przez producentów prądnicy oraz silnika spalinowego. Moc znamionowa czynna prądnicy $\mathrm{P}_{\mathrm{Pn}}$ powinna być nie mniejsza niż moc znamionowa całego zespołu prądotwórczego $\mathrm{P}_{\mathrm{An}}$. Moc znamionowa generatora $\mathrm{z}$ reguły podawana jest jako moc pozorna $\mathrm{S}_{\mathrm{Pn}}$ (w woltamperach, VA) dla współczynnika mocy $\cos \varphi=$ $=0,8$ [2]. Jeżeli z tą samą wartością współczynnika mocy ma być wyrażona moc całego zespołu prądotwórczego, należy przyjąć - wzór (1).

Moc elektryczna oddawana przez prądnicę jest pomniejszona w relacji do mocy mechanicznej do niej dostarczonej z uwagi na występowanie strat w maszynie elektrycznej. Moc mechaniczna $\mathrm{P}_{\mathrm{Sn}}$ na wale silnika spalinowego (tzw. moc rzeczywista), potrzebna do uzyskania założonej mocy elektrycznej znamionowej zespołu na wyjściu prądnicy, może być oszacowana przy znanej sprawności $\eta_{\mathrm{Pn}}$ prądnicy, przy założeniu zbliżonych do znamionowych warunków pracy. Ponadto konieczne jest zapewnienie tzw. mocy dodatkowej silnika spalinowego [4], przeznaczonej na cele regulacyjne w stanach przejściowych. Moc ta z reguły wynosi $10 \%$ mocy znamionowej. Powyższe warunki opisane są zależnością (2).

Oszacowana moc znamionowa agregatu $\mathrm{P}_{\text {An }}$ będzie zatem mniejszą z wartości otrzymanych według zależności (1) i (2). Oszacowana na podstawie parametrów silnika i prądnicy moc znamionowa rozważanego agregatu jest ograniczona przez moc silnika i wynosi $\mathrm{P}_{\mathrm{An}(\mathrm{T})}=7156 \mathrm{~W}$.

\section{Określanie mocy znamionowej agregatu na podstawie badań doświadczalnych}

Dane katalogowe podzespołów agregatu, podane dla pewnych założonych warunków pracy, mogą ulec zmianie po ich montażu w kompletnym agregacie. Wyniknąć to może na przykład z pogorszonych warunków chłodzenia spowodowanych zamknięciem podzespołów w obudowie oraz ze wzajemnego oddziaływania termicznego prądnicy i silnika. Na faktyczną moc agregatu może mieć też wpływ interakcja regulatora prędkości kątowej silnika oraz regulatora wzbudzenia prądnicy [3]. Wskazana jest zatem weryfikacja wartości mocy kompletnego zestawu prądotwórczego eksperymentalnie.

Moc znamionowa agregatu zdeterminowana jest przez wartości odpowiednich parametrów, zdefiniowane w taki sposób, aby zapewnić zakładany czas użytkowania agregatu, ograniczone oddziaływanie urządzenia na środowisko oraz poprawne warunki pracy odbiorników mocy elektrycznej. Typowym ograniczeniem mocy prądnicy jest zachowanie określonej temperatury uzwojeń [4]. Ze względu na trwałość izolacji uzwojeń generatora jej temperatura nie powinna przekraczać wartości dopuszczalnej. Wartość temperatury dopuszczalnej zależy od tzw. klasy materiału, z którego wykonano powłokę izolacyjną. Na przykład dla klasy izolacji $\mathrm{F}$ dopuszczalna długotrwale temperatura to 
Methods for measuring the increase in the temperature of the windings are specified in the standard mentioned above. A resistive method has the greatest practical significance. The method, which involves analysis of changes in the resistance of motor windings before and after the load test, is based on the following formula describing the increase of windings temperature $\Theta$ :

$$
\dot{\mathrm{E}}=\frac{\mathrm{R}_{\mathrm{G}}-\mathrm{R}_{\mathrm{Z}}}{\mathrm{R}_{\mathrm{G}}} \cdot\left(235+9_{Z}\right)-\left(\vartheta_{A}-\vartheta_{Z}\right),
$$

where: $\mathrm{R}_{\mathrm{z}} \mathrm{i} \vartheta_{\mathrm{z}}$-windings resistance and ambient temperature before load operation test $\left(\Omega,{ }^{\circ} \mathrm{C}\right), \mathrm{R}_{\mathrm{G}}$ and $\vartheta_{\mathrm{A}}$ - windings resistance and ambient temperature after load operation test $\left(\Omega,{ }^{\circ} \mathrm{C}\right)$.

It should be noted that in the case of using indirect method for determining the increase of temperature, the acceptable values of the increase should be reduced. For example, for $\mathrm{F}$ insulation class the permissible increase of temperature is not $155-40=115 \mathrm{~K}$, but $105 \mathrm{~K}$ [2]. This correction is necessary when we consider unequal distribution of temperature along the entire length of the windings. Average value of resistance is measured, but it is the area with the highest temperature, which is important for durability of the insulation [1].

Another factor which may decide about the value of rated power of a generator set is the generator output voltage, which cannot be permanently reduced by more than $10 \%$ in relation to the rated value [5]. The value of output voltage depends on the load current (voltage drop on the winding resistance), but also on functioning of the generator field excitation control, whose internal structure and settings are usually unknown.

Angular velocity of the motor shaft is another important parameter. Proper working conditions of the generator set determine the range of changes in frequency of generator output voltage. This frequency, in the case of a synchronous generator, is directly related to the rotor angular velocity. The lower limit of frequency, which depends on the requirements of electrical devices powered by a generator set, is strictly defined. Specific limits can be found in standard [5], for example - for less demanding devices like heaters or kitchen ovens, the output voltage frequency should not be reduced by more than $8 \%$ in relation to the idle run frequency of a generator set.

\subsection{Measurement stand}

Load tests (so-called functional trial) of the generator set should be performed for approximately $25 \%, 50 \%, 75 \%$ and $100 \%$ of the assumed rated power [6]. It is necessary to use the adjustable electrical load (resistance $\mathrm{R}$ and inductance $\mathrm{L}$ ) with sufficient power level and possibility of setting the load parameters corresponding to the set of power values listed above, at the assumed level of the power coefficient.

The considered generator set was tested using the measurement system, whose diagram is shown in Fig. 1. Due to the possible slight asymmetry of the load and/or electric generator, the measurements of active power, voltage and current are performed in each phase. Additionally, in selected
$155{ }^{\circ} \mathrm{C}$ [2]. Tak zdefiniowany warunek jest niepraktyczny ze względu na zmieniające się warunki chłodzenia maszyny oraz trudności praktyczne związane z wyznaczeniem bezwzględnej wartości temperatury. $Z$ tego powodu w normie PN-EN 60034-1 posłużono się pojęciem dopuszczalnego przyrostu temperatury, zakładając, że temperatura otoczenia nie przekracza $40{ }^{\circ} \mathrm{C}$.

Metody pomiaru przyrostu temperatury uzwojeń ujęte zostały w powyższej normie. Największe znaczenie praktyczne ma metoda rezystancyjna polegająca na analizie zmiany rezystancji uzwojeń silnika przed próbą obciążeniową i po próbie obciążeniowej, bazująca na zależności (3), opisującej przyrost temperatury uzwojeń $\Theta$,

gdzie: $R_{Z}$ i $\vartheta_{Z}$-rezystancja uzwojeń i temperatura otoczenia przed próbą obciążeniową $\left(\Omega,{ }^{\circ} \mathrm{C}\right), \mathrm{R}_{\mathrm{G}} \mathrm{i} \vartheta_{\mathrm{A}}$ - rezystancja uzwojeń i temperatura otoczenia po zakończeniu próby $\left(\Omega,{ }^{\circ} \mathrm{C}\right)$.

Należy zwrócić uwagę, że dla pośredniego sposobu wyznaczania przyrostu temperatury dopuszczalne wartości są dodatkowo pomniejszone. Na przykład dla izolacji klasy $\mathrm{F}$ dopuszczalny przyrost nie wynosi $155-40=115 \mathrm{~K}$, a $105 \mathrm{~K}$ [2]. Korekta ta ma na celu uwzględnienie nierównomiernego rozkładu temperatury na całej długości uzwojeń - mierzona jest uśredniona wartość rezystancji, zaś na trwałość izolacji ma wpływ obszar o najwyższej temperaturze [1].

Innym czynnikiem, który może zadecydować o wartości mocy znamionowej agregatu jest napięcie wyjściowe prądnicy, które nie może obniżyć się trwale więcej niż o 10 \% względem wartości znamionowej [5]. Wartość napięcia wyjściowego zależy od pobieranego prądu (spadki na rezystancji uzwojeń), ale także od działania regulatora wzbudzenia prądnicy, którego struktura i nastawy są zazwyczaj nieznane.

Istotnym parametrem silnika jest prędkość kątowa wału napędowego. Prawidłowe warunki pracy agregatu determinują zakres zmian częstotliwości napięcia wyjściowego prądnicy. Częstotliwość ta, w odniesieniu do prądnicy synchronicznej, ma bezpośredni związek z prędkością kątową wirnika. Zdefiniowana jest dolna graniczna wartość częstotliwości, która zależy od wymagań odbiorników elektrycznych. Konkretne wartości graniczne znajdują się w publikacji [5], na przykład - dla mało wymagających urządzeń typu piece grzewcze lub kuchnie częstotliwość napięcia wyjściowego nie powinna obniżyć się więcej niż o $8 \%$ względem częstotliwości przy biegu jałowym agregatu.

\subsection{Stanowisko pomiarowe}

Badania obciążeniowe (tzw. próba funkcjonalna) zespołu prądotwórczego powinny być wykonywane dla około $25 \%$, $50 \%, 75 \%$ i $100 \%$ zakładanej mocy znamionowej [6]. Konieczne jest zatem regulowane obciążenie elektryczne o odpowiedniej mocy i możliwości nastaw rezystancji $\mathrm{R}$ i indukcyjności L odpowiadających zestawowi wartości mocy wymienionemu powyżej, przy zakładanym współczynniku mocy.

Rozważany agregat prądotwórczy poddano badaniom, wykorzystując układ pomiarowy, którego schemat przedstawiono na rys. 1 . Z uwagi na możliwą drobną niesymetrię 
phases, meters of frequency and power coefficient have been connected. The power coefficient meter allows for convenient setting of load parameters. The exact value of the power coefficient can be determined based on the measurement values of the power meter, ammeter and voltmeter.

The set of devices used for the measurement of windings resistance consists of a stabilized, regulated DC supply, ammeter and millivoltmeter, as well as a set of connectors. The possibility of fast disconnecting of the load and measuring the resistance in each winding of the generator is very important due to time limitations. For units with power not exceeding $50 \mathrm{~kW}$, measurement of resistance has to be performed three times in each phase ( 9 current and voltage readings in total) within 30 seconds from disconnecting the load and stopping the engine of the generator set [2].

In addition to the measurements performed with the equipment shown in Fig. 1 it is necessary to measure the ambient temperature, whose value is present in the formula (1). Moreover, it is recommended to use two temperature sensors - one on the combustion engine and the other on the electrical generator radiator. Observation of external temperature of the devices allows us to draw conclusions regarding the settling of internal temperature condition for both devices, particularly the temperature of the windings.

\subsection{Rated power evaluation procedure}

Before commencing the load tests, it is necessary to measure the $R_{Z}$ resistance of electric generator windings. During this measurement the windings temperature should be equal to ambient temperature. The generator set, due to the high thermal inertia, should be set in the testing place (eg. outside the room) some time earlier, so that the temperature difference between the generator windings and the environment does not exceed $2{ }^{\circ} \mathrm{C}$ [2]. The general testing algorithm is shown in Fig. 2. obciążenia i/lub generatora, pomiar mocy czynnej, napięcia i prądu wykonywany jest w każdej fazie. Dodatkowo w wybranych fazach umieszczono częstotliwościomierz oraz miernik współczynnika mocy. Ten drugi ma jedynie na celu umożliwienie wygodnego nastawiania parametrów obciążenia. Dokładną wartość współczynnika mocy można wyznaczyć na podstawie wskazań watomierza, amperomierza i woltomierza.

Do pomiaru rezystancji uzwojeń przewidziano zespół przyrządów składający się ze stabilizowanego, regulowanego zasilacza napięcia stałego, amperomierza i miliwoltomierza, a także zestawu łączników. Możliwość sprawnego odłączenia obciążenia i pomiaru rezystancji każdej z faz jest bardzo istotna ze względu na ograniczenia czasowe. Dla agregatów o mocy nieprzekraczającej $50 \mathrm{~kW}$ należy wykonać po 3 pomiary rezystancji w każdej z faz (łącznie 9 odczytów prądu i napięcia) w ciągu $30 \mathrm{~s}$ od odłączenia zasilania i zatrzymania silnika agregatu [2].

Oprócz przyrządów pomiarowych przedstawionych na rys. 1 niezbędny jest pomiar temperatury otoczenia, której wartość występuje w zależności (1). Zaleca się także zastosowanie dwóch czujników temperatury - po jednym odpowiednio na korpusie silnika i radiatorze prądnicy. Obserwacja temperatury zewnętrznej urządzeń pozwala na wnioskowanie na temat ustalenia się temperatury wewnętrznej, przede wszystkim temperatury uzwojeń.

\subsection{Procedura wyznaczania mocy znamionowej}

Przed rozpoczęciem prób obciążeniowych konieczny jest pomiar rezystancji uzwojeń prądnicy $\mathrm{R}_{\mathrm{z}}$. Podczas tego pomiaru temperatura uzwojeń powinna być równa temperaturze otoczenia. Agregat, ze względu na dużą bezwładność cieplną, powinien być ustawiony w miejscu badania (np. na zewnątrz pomieszczenia) odpowiednio wcześniej, aby różnica temperatury uzwojeń prądnicy oraz otoczenia była nie większa niż $2{ }^{\circ} \mathrm{C}[2]$. Ogólny algorytm przeprowadza-

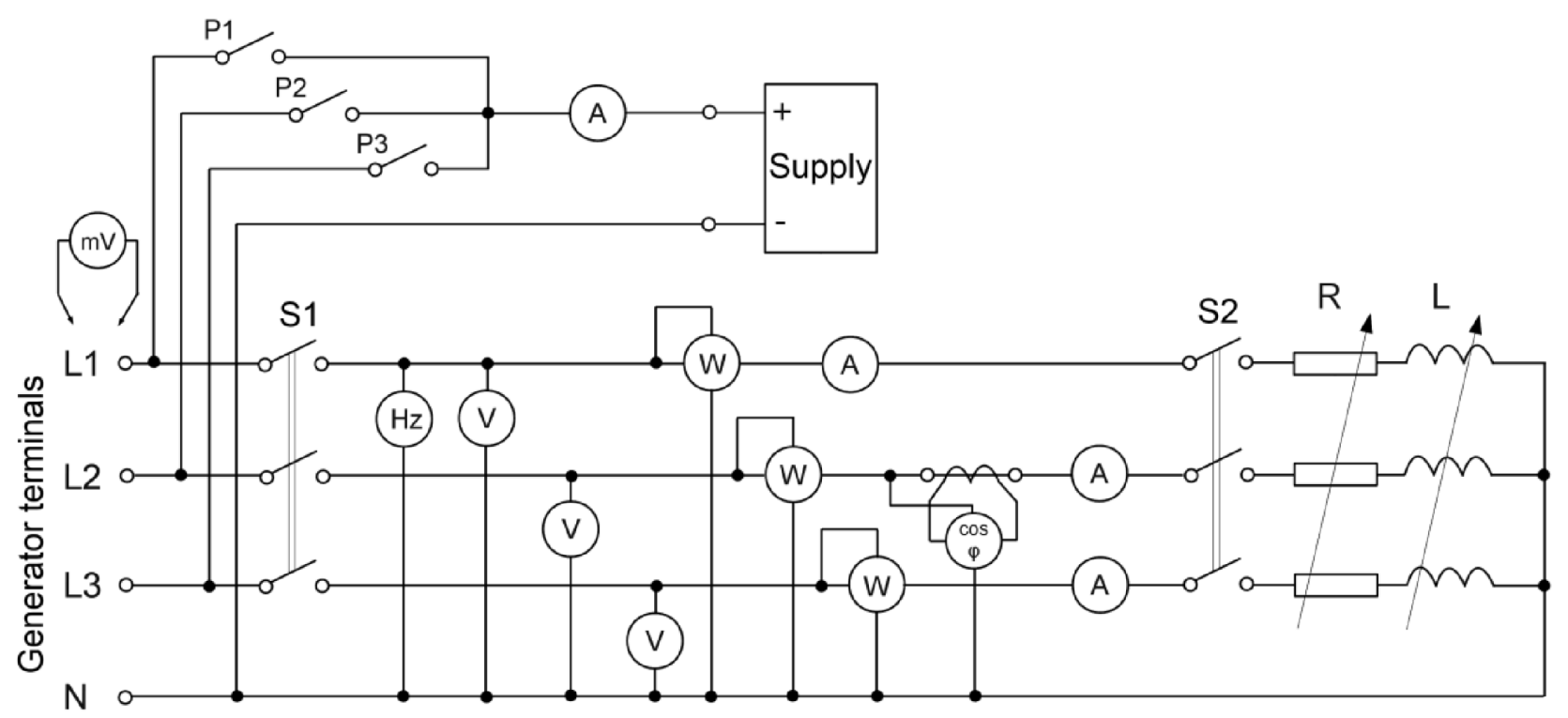

Fig. 1. Proposed electrical diagram of the test circuit dedicated to evaluate generator set nominal power Rys. 1. Proponowany schemat ukladu pomiarowego do wyznaczania mocy znamionowej agregatu prądotwórczego 
Measurement of windings temperature can be performed using the technical method for resistance measurement. The measurement should be performed three times for each phase - for three different values of the measured current. The value of this current should not exceed $10 \%$ of rated current for the generator. Measurements for each phase should be averaged.

After starting the generator set, it is recommended to warm up the combustion engine before turning on the load. Measurement of the engine body temperature allows us to establish the time when the engine temperature stops increasing. During idle running (before applying the load), it is advisable to make a note of operating parameters, particularly of the voltage frequency to which the limit value defined in p. 3 is related.

Tests with load should be performed in sequence with the load gradually increasing to the specified values. The duration of the test is relatively long due to necessity of achieving, in each test, thermal equilibrium of the windings. Stable thermal condition for the testing unit was achieved after about 80 min. Thermal stability of the windings is achieved when the temperature of electrical generator radiator stops increasing. According to standard PN-EN 60034-1 it has to be assumed that the thermal equilibrium occurred when the temperature measured in several parts of the machine does not increase faster than $2 \mathrm{~K} / \mathrm{h}$. However, this condition is very difficult to verify, particularly for the generator set with closed construction. It would be necessary to install numerous sensors on the

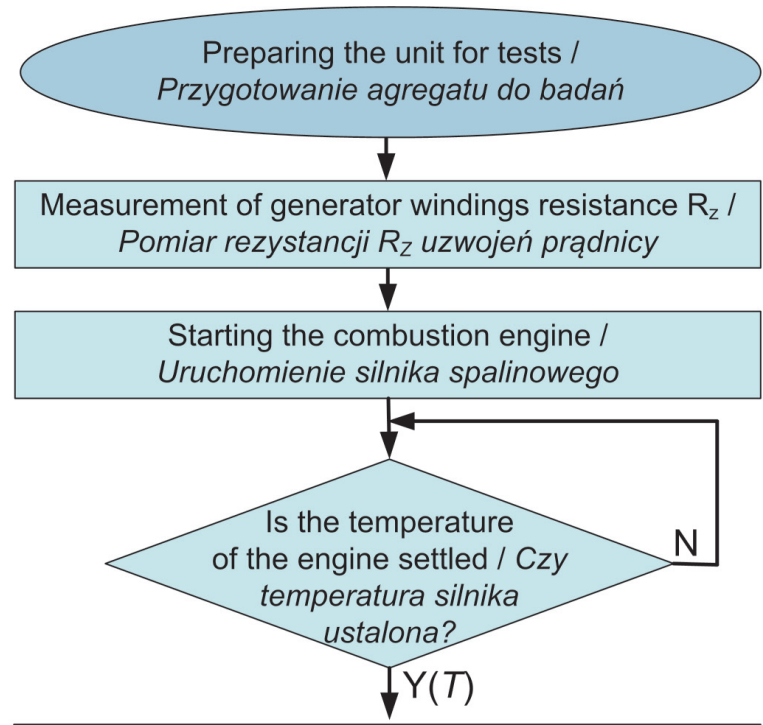

Reading the parameters of generator idle running / Odczyt parametrów biegu jałowego prądnicy

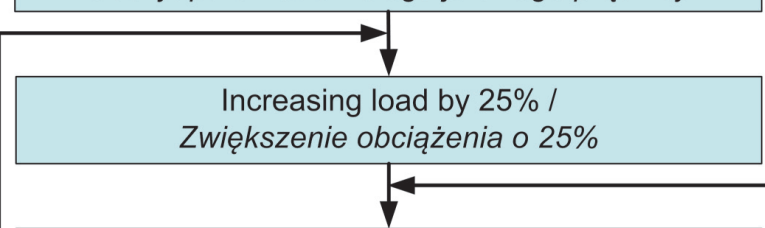

Reading (periodical) of electrical parameters and temperature / Odczyt (cykliczny) parametrów elektrycznych oraz temperatur

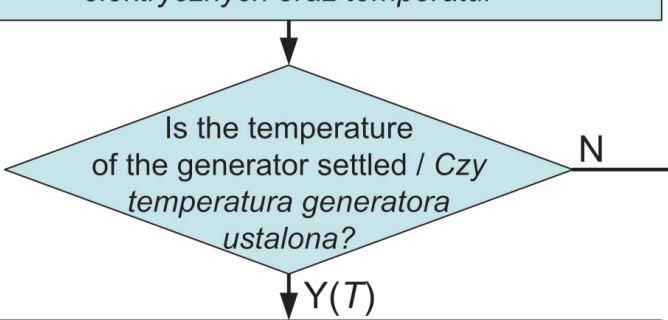

Turning off the load, stopping the combustion engine, measurement of generator windings resistance $\mathrm{R}_{\mathrm{G}} /$ Odłączenie obciążenia, wyłączenie silnika spalinowego, pomiar rezystancji $R_{G}$ uzwojeń prądnicy

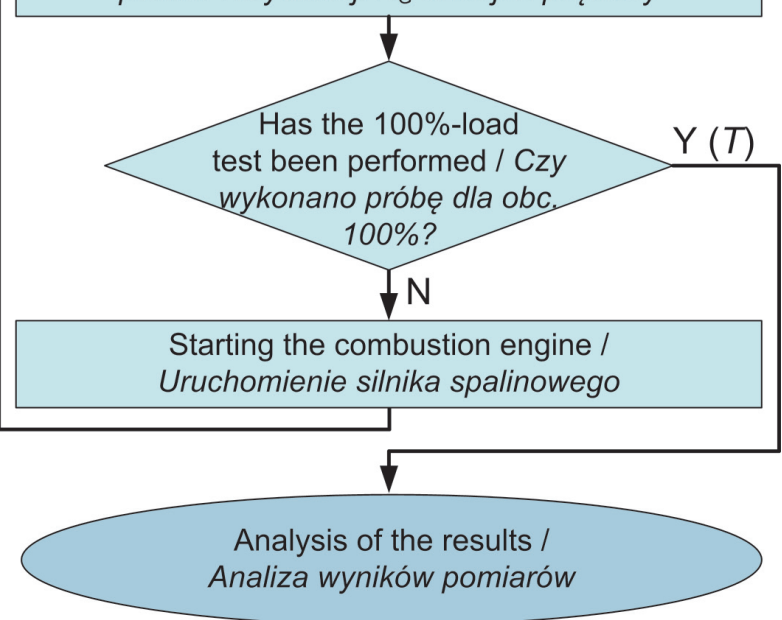

Fig. 2. Procedure of generator set nominal power determination Rys. 2. Proces wyznaczania mocy znamionowej agregatu nia badań przedstawiono na rys. 2 .

Pomiar temperatury uzwojeń można wykonać pośrednio - na podstawie pomiaru rezystancji metodą techniczną. Należy wykonać pomiar trzykrotnie dla każdej z faz - dla trzech różnych wartości prądu pomiarowego. Wartość prądu nie powinna przekraczać $10 \%$ wartości znamionowej dla generatora. Pomiary należy uśrednić w ramach każdej z faz.

Po uruchomieniu agregatu zalecane jest rozgrzanie silnika spalinowego, przed załączeniem obciążenia. Pomiar temperatury korpusu silnika pozwala na ustalenie czasu, w którym silnik przestaje się nagrzewać. Podczas pracy jałowej (przed załączeniem obciążenia) wskazane jest zanotowanie parametrów pracy, szczególnie częstotliwości napięcia, do której odnosi się graniczna wartość wymieniona $\mathrm{w}$ rozdz. 3.

Próby obciążeniowe należy wykonywać kolejno, sukcesywnie zwiększając obciążenie do ustalonych wartości. Z uwagi na konieczność osiągnięcia równowagi termicznej uzwojeń w każdej próbie czas ich trwania jest relatywnie długi. Dla badanego urządzenia termiczny stan ustalony osiągano po ok. $80 \mathrm{~min}$. O ustaleniu się temperatury uzwojeń świadczy ustanie przyrostu temperatury radiatora prądnicy. Według wytycznych normy PN-EN 60034-1 należy przyjąć, że wystąpił stan równowagi termicznej, temperatura mierzona w kilku częściach maszyny nie wzrasta szybciej niż $2 \mathrm{~K} / \operatorname{godz}$. Jest to jednak warunek trudny do sprawdzenia, szczególnie w agregatach o budowie zamkniętej. Wymagałby zainstalowania na prądnicy wielu czujników, 


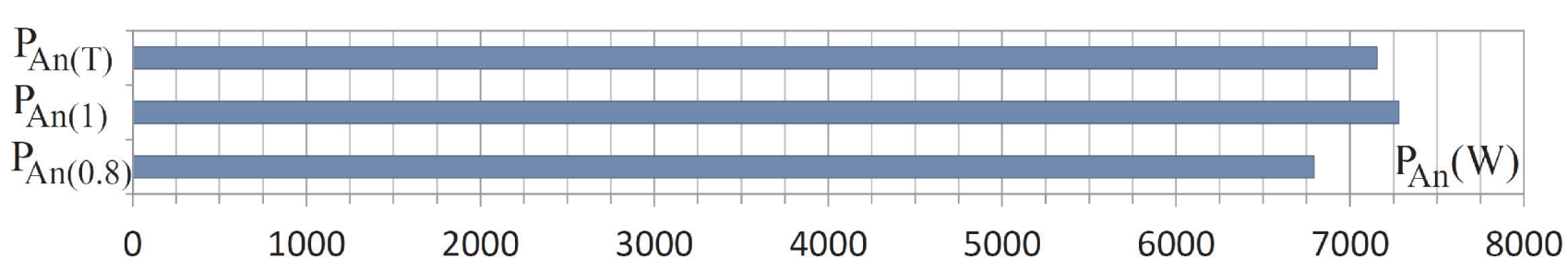

Fig. 3. Comparison of power evaluation results

Rys. 3. Porównanie mocy uzyskanych trzema metodami

generator because opening the unit casing during the test is not recommended due to changes in cooling conditions. For that reason it is recommended that, during the tests, the measured electrical parameters are noted down repeatedly and averaged in the end [2].

Once the stable thermal condition of the generator had been achieved, the load should be disconnected, the unit turned off and, after stopping the motor shaft (due to the voltage inducted during the movement of the generator's rotor) the measurement of windings resistance should be performed.

\section{Measurement results}

The examined generator set has been subjected to load tests for the two methods permitted by the standard ISO $8528-6$, i.e. at the rated power coefficient and for a simplified measurement procedure, with the power factor equal one. The results for the rated power coefficient are presented in ponieważ otwarcie obudowy w trakcie testu nie jest wskazane z uwagi na zmianę warunków chłodzenia. Dlatego podczas trwania prób obciążeniowych zaleca się wielokrotne spisywanie parametrów elektrycznych w równych odstępach czasu, a na końcu ich uśrednienie [2].

Po osiągnięciu ustalonego stanu termicznego generatora należy odłączyć obciążenie, wyłączyć agregat, a po zatrzymaniu wału silnika (ze względu na napięcia indukowane podczas ruchu wirnika prądnicy) wykonać pomiar rezystancji uzwojeń.

\section{Wyniki pomiarów}

Omawiany zespół prądotwórczy poddano badaniom obciążeniowym przy zastosowaniu dwóch metod dopuszczalnych przez normę PN-ISO 8528-6, tj. przy znamionowym współczynniku mocy oraz dla uproszczonej procedury pomiarowej przy współczynniku mocy równym jedności. Wyniki dla znamionowego współczynnika mocy przedstawiono w tab. 1, a dla współczynnika mocy równego jedności w tab. 2. Nie-

Table 1. Experimental results for load with power factor $\cos \varphi=0.8$

Tabela 1. Wyniki prób agregatu dla obciążenia z $\cos \varphi=0,8$

\begin{tabular}{|c|c|c|c|c|c|c|}
\hline$\% \mathrm{P}_{\mathrm{n}}$ & $\mathrm{U}_{\mathrm{L} 1}(\mathrm{~V})$ & $\mathrm{U}_{\mathrm{L} 2}(\mathrm{~V})$ & $\mathrm{U}_{\mathrm{L} 3}(\mathrm{~V})$ & $\mathrm{I}_{\mathrm{L} 1}(\mathrm{~A})$ & $\mathrm{I}_{\mathrm{L} 2}(\mathrm{~A})$ & $\mathrm{I}_{\mathrm{L} 3}(\mathrm{~A})$ \\
\hline 0 & $232 \pm 3$ & $234 \pm 3$ & $231 \pm 3$ & - & - & - \\
\hline 15 & $232 \pm 3$ & $233 \pm 3$ & $231 \pm 3$ & $2.228 \pm 0.025$ & $2.263 \pm 0.013$ & $2.168 \pm 0.025$ \\
\hline 44 & $232 \pm 3$ & $234 \pm 3$ & $230 \pm 3$ & $6.7 \pm 0.1$ & $6.66 \pm 0.05$ & $6.62 \pm 0.05$ \\
\hline 77 & $233 \pm 3$ & $235 \pm 3$ & $231 \pm 3$ & $10.7 \pm 0.2$ & $10.6 \pm 0.1$ & $10.46 \pm 0.15$ \\
\hline 94 & $216 \pm 3$ & $218 \pm 3$ & $214 \pm 3$ & $14.5 \pm 0.2$ & $14.1 \pm 0.1$ & $14.46 \pm 0.15$ \\
\hline$\% \mathrm{P}_{\mathrm{n}}$ & $\mathrm{P}_{\mathrm{L} 1}(\mathrm{~W})$ & $\mathrm{P}_{\mathrm{L} 2}(\mathrm{~W})$ & $\mathrm{P}_{\mathrm{L} 3}(\mathrm{~W})$ & $\mathrm{S}_{\mathrm{L} 1}(\mathrm{VA})$ & $\mathrm{S}_{\mathrm{L} 2}(\mathrm{VA})$ & $\mathrm{S}_{\mathrm{L} 3}(\mathrm{VA})$ \\
\hline 0 & - & - & - & - & - & - \\
\hline 15 & $410 \pm 10$ & $409 \pm 5$ & $391 \pm 5$ & $517 \pm 11$ & $527 \pm 9$ & $500 \pm 11$ \\
\hline 44 & $1150 \pm 10$ & $1210 \pm 10$ & $1170 \pm 10$ & $1554 \pm 36$ & $1555 \pm 27$ & $1520 \pm 27$ \\
\hline 77 & $1840 \pm 20$ & $1940 \pm 20$ & $1900 \pm 20$ & $2493 \pm 66$ & $2482 \pm 46$ & $2414 \pm 54$ \\
\hline 94 & $2450 \pm 20$ & $2480 \pm 20$ & $2540 \pm 20$ & $3128 \pm 71$ & $3086 \pm 56$ & $3095 \pm 63$ \\
\hline$\% \mathrm{P}_{\mathrm{n}}$ & $\mathrm{P}_{\text {tot }}(\mathrm{W})$ & $\mathrm{S}_{\mathrm{tot}}(\mathrm{VA})$ & $\cos \varphi$ & $\mathrm{f}(\mathrm{Hz})$ & $\Theta\left({ }^{\circ} \mathrm{C}\right)$ & \\
\hline 0 & - & - & - & $52.50 \pm 0.27$ & - & \\
\hline 15 & $1211 \pm 24$ & $1545 \pm 29$ & $0.784 \pm 0.022$ & $52.25 \pm 0.27$ & $20.9 \pm 2.8$ & \\
\hline 44 & $3518 \pm 35$ & $4630 \pm 90$ & $0.760 \pm 0.017$ & $51.50 \pm 0.26$ & $36.5 \pm 2.9$ & \\
\hline 77 & $5680 \pm 70$ & $7390 \pm 170$ & $0.77 \pm 0.02$ & $50.50 \pm 0.26$ & $61.6 \pm 3.1$ & \\
\hline 94 & $7470 \pm 70$ & $9300 \pm 190$ & $0.803 \pm 0.019$ & $49.25 \pm 0.25$ & $92.7 \pm 3.5$ & \\
\hline
\end{tabular}


Table 2. Experimental results for load with power factor $\cos \varphi=1$

Tabela 2. Wyniki prób agregatu dla obciążenia z $\cos \varphi=1$

\begin{tabular}{|c|c|c|c|c|c|c|}
\hline$\% \mathrm{P}_{\mathrm{n}}$ & $\mathrm{U}_{\mathrm{L} 1}(\mathrm{~V})$ & $\mathrm{U}_{\mathrm{L} 2}(\mathrm{~V})$ & $\mathrm{U}_{\mathrm{L} 3}(\mathrm{~V})$ & $\mathrm{I}_{\mathrm{L} 1}(\mathrm{~A})$ & $\mathrm{I}_{\mathrm{L} 2}(\mathrm{~A})$ & $\mathrm{I}_{\mathrm{L} 3}(\mathrm{~A})$ \\
\hline 0 & $233 \pm 3$ & $232 \pm 3$ & $231 \pm 3$ & - & - & - \\
\hline 28 & $233 \pm 3$ & $231 \pm 3$ & $230 \pm 3$ & $3.150 \pm 0.025$ & $3.211 \pm 0.013$ & $3.220 \pm 0.025$ \\
\hline 54 & $232 \pm 3$ & $230 \pm 3$ & $230 \pm 3$ & $6.0 \pm 0.1$ & $6.03 \pm 0.05$ & $6.09 \pm 0.05$ \\
\hline 80 & $233 \pm 3$ & $230 \pm 3$ & $229 \pm 3$ & $9.4 \pm 0.2$ & $9.3 \pm 0.1$ & $9.45 \pm 0.15$ \\
\hline 97 & $233 \pm 3$ & $230 \pm 3$ & $230 \pm 3$ & $11.3 \pm 0.2$ & $11.2 \pm 0.1$ & $11.33 \pm 0.15$ \\
\hline $100 *$ & $227 \pm 3$ & $223 \pm 3$ & $223 \pm 3$ & $12.4 \pm 0.2$ & $11.8 \pm 0.1$ & $12.25 \pm 0.15$ \\
\hline$\% \mathrm{P}_{\mathrm{n}}$ & $\mathrm{P}_{\mathrm{L} 1}(\mathrm{~W})$ & $\mathrm{P}_{\mathrm{L} 2}(\mathrm{~W})$ & $\mathrm{P}_{\mathrm{L} 3}(\mathrm{~W})$ & $\mathrm{P}_{\mathrm{tot}}(\mathrm{W})$ & $\mathrm{f}(\mathrm{Hz})$ & $\Theta\left({ }^{\circ} \mathrm{C}\right)$ \\
\hline 0 & - & - & - & - & $53.00 \pm 0.27$ & - \\
\hline 28 & $740 \pm 10$ & $738 \pm 5$ & $737 \pm 5$ & $2216 \pm 24$ & $52.25 \pm 0.27$ & $23 \pm 3$ \\
\hline 54 & $1390 \pm 10$ & $1500 \pm 10$ & $1390 \pm 10$ & $4287 \pm 35$ & $51.50 \pm 0.26$ & $31 \pm 3$ \\
\hline 80 & $2150 \pm 20$ & $2120 \pm 20$ & $2140 \pm 20$ & $6410 \pm 70$ & $50.50 \pm 0.26$ & $45.6 \pm 3.1$ \\
\hline 97 & $2590 \pm 20$ & $2550 \pm 20$ & $2560 \pm 20$ & $7700 \pm 70$ & $50.00 \pm 0.25$ & $59.9 \pm 3.3$ \\
\hline $100 *$ & $2700 \pm 20$ & $2620 \pm 20$ & $2680 \pm 20$ & $8010 \pm 70$ & $47.25 \pm 0.24$ & - \\
\hline
\end{tabular}

Table 1, and for the power coefficient equal one in Table 2. The uncertainty of the measurements was determined based on the current recommendations of GUM [7, 8, 9].

During the full tests (with $\cos \varphi=0.8$ ) the increase of the load level above $90 \%$ of the assumed rated value resulted in sudden reduction of generated voltage values. This decrease probably denotes the reaction of generator field excitation controller to a significant decrease in the motor angular velocity (aiming at limiting the load current). For the last test the load value was selected in such a way that the generator phase voltages were at the borderline of the value specified in [5]. Since the other important operating parameters fell within the acceptable ranges, the power generated during the last test (94 $\%$ ) was assumed to be the maximum power value.

In the course of simplified tests (with $\cos \varphi=1$ ), during the long-term load at the level corresponding to $100 \%$ of the assumed rated power, the combustion engine was overheated. Therefore, an additional test was performed for a slightly lower load level (97\%). During this test, all relevant operating parameters were normal, which allows for accepting this value as maximum power.

Considering the normative relations between the maximum and rated power, defined by standards, the following values of rated power were obtained:

- for a complete test (with $\cos \varphi=0.8)$ : $\mathrm{P}_{\mathrm{An}(0.8)}=6795 \pm 63 \mathrm{~W}$, - for a simplified test (with $\cos \varphi=1$ ): $\mathrm{P}_{\mathrm{An}(1)}^{\mathrm{An}(0.8)}=7282 \pm 63 \mathrm{~W}$.

The comparison of the results obtained for all three methods of evaluating rated power of a generator set is shown in Fig. 3.

\section{Conclusions}

Depending on the evaluating method used, it is possible, for the same generator set, to obtain different values of rated power. The results obtained by measurements with pewność pomiarów określono na podstawie obowiązujących zaleceń GUM [7, 8, 9].

Podczas badań pełnych $(\cos \varphi=0,8)$ zwiększanie obciążenia powyżej 90 \% założonej wartości znamionowej skutkowało gwałtownym spadkiem napięć fazowych. Spadek ten jest przypuszczalnie reakcją regulatora wzbudzenia prądnicy na znaczne zmniejszenie się prędkości kątowej silnika (dążenie do ograniczenia prądu obciążenia). Dla ostatniej próby obciążenie dobrano zatem tak, aby napięcia fazowe generatora były na granicy wartości określonej w publikacji [5]. Ponieważ pozostałe istotne parametry pracy mieściły się w obranych przedziałach, za moc maksymalną przyjęto moc oddawaną przez generator podczas ostatniej próby $(94 \%)$.

W czasie badań uproszczonych $(\cos \varphi=1)$, podczas długotrwałego obciążenia odpowiadającego 100-procentom założonej mocy znamionowej, silnik uległ przegrzaniu. $\mathrm{Z}$ tego względu wykonano dodatkową próbę dla nieznacznie mniejszego obciążenia (97 \%). Podczas tej próby wszystkie istotne parametry pracy były prawidłowe, co pozwala na przyjęcie mocy maksymalnej na jej podstawie.

Uwzględniając określone przez przepisy normatywne zależności pomiędzy mocą maksymalną a mocą nominalną, uzyskano następujące wartości wyznaczonych mocy nominalnych:

- dla próby pełnej $(\cos \varphi=0,8): \mathrm{P}_{\mathrm{An}(0,8)}=6795 \pm 63 \mathrm{~W}$, - dla próby uproszczonej $(\cos \varphi=1): \mathrm{P}_{\mathrm{An}(1)}=7282 \pm 63 \mathrm{~W}$.

Porównanie wyników otrzymanych dla wszystkich trzech metod wyznaczania mocy znamionowej agregatu prądotwórczego przedstawiono na rys. 3 .

\section{Podsumowanie}

W zależności od zastosowanej metody można dla tego samego agregatu uzyskać inne wartości mocy znamionowej. 
rated power coefficient should be considered as the most authoritative ones, as they are established for target operating conditions and load. Other methods, which assume certain simplifications, result in a power value overstated by a few percent.

Using a simplified theoretical or experimental method may therefore lead to incorrect evaluation of the generator set's rated power and, consequently, to incorrect selection and exploitation of these devices. Manufacturers of generator sets should be aware of this, in order to be able to offer, to their customers, the products whose parameters are compatible with the declared ones.
Za najbardziej miarodajne należy uznać uzyskane przy pomiarach ze znamionowym współczynnikiem mocy, ponieważ wyznaczane są one dla docelowych warunków pracy oraz charakteru obciążenia. Pozostałe metody, opierające się na odpowiednich założeniach upraszczających, dają wyniki zawyżone o kilka procent.

Zastosowanie metody teoretycznej lub uproszczonej metody doświadczalnej może zatem prowadzić do nieprawidłowego określenia mocy znamionowej i w konsekwencji do niepoprawnego doboru i eksploatacji tych urządzeń. Producenci agregatów powinni mieć świadomość takiego stanu rzeczy, aby móc oferować klientom produkty o parametrach zgodnych z deklarowanymi.

\footnotetext{
Abbreviations /Oznaczenia

$\% \mathrm{P}_{\mathrm{n}} \quad$ power value related to the assumed rated power/ wartość mocy odniesiona do założonej mocy znamionowej

$\mathrm{L}_{1}, \mathrm{~L}_{2}, \mathrm{~L}_{3} \quad$ symbols of generator phases/oznaczenia faz generatora

$\mathrm{U}_{\mathrm{L} 1}, \mathrm{U}_{\mathrm{L} 2}, \mathrm{U}_{\mathrm{L} 3}$ voltage values for each generator phase/wartości napięć fazowych generatora

$\mathrm{I}_{\mathrm{L} 1}, \mathrm{I}_{\mathrm{L} 2}, \mathrm{I}_{\mathrm{L} 3}$ generator current values/wartości prądu generatora

$\mathrm{P}_{\mathrm{L} 1}, \mathrm{P}_{\mathrm{L} 2}, \mathrm{P}_{\mathrm{L} 3}$ active power values/wartości mocy czynnej

$\mathrm{S}_{\mathrm{L} 1}, \mathrm{~S}_{\mathrm{L} 2}, \mathrm{~S}_{\mathrm{L} 3}$ apparent power values/wartości mocy pozornej

$\mathrm{P}_{\text {tot }}, \mathrm{S}_{\text {tot }}$ total value of the consumed active and apparent power/ catkowite wartości pobieranej mocy czynnej i pozornej
}

$\cos \varphi \quad$ calculated power factor/wyliczony współczynnik mocy

f generator voltage frequency/częstotliwość napięcia generatora

$\Theta \quad$ temperature increase of the windings at the end of each stage of the generator set test/przyrost temperatury uzwojen generatora po zakończeniu próby cząstkowej test has not been completed due to activation of engine thermal protection/próba nie została dokończona z powodu zadziałania zabezpieczenia termicznego silnika spalinowego

\section{Bibliography/Literatura}

[1] Latek W.: Badanie maszyn elektrycznych w przemyśle. WNT, Warszawa 1987.

[2] PN-EN 60034-1:2011 Maszyny elektryczne wirujące - Część 1: Dane znamionowe i parametry.

[3] PN-EN 60034-22:2010 Maszyny elektryczne wirujące -Część 22: Prądnice prądu przemiennego do zespołów prądotwórczych napędzanych trokowymi silnikami spalinowymi.

[4] PN-ISO 8528-1:1996 Zespoły prądotwórcze prądu przemiennego napędzane silnikiem spalinowym tłokowym - Zastosowanie, klasyfikacja i wymagania eksploatacyjne.

[5] PN-ISO 8528-5:1997 Zespoły prądotwórcze prądu przemiennego napędzane silnikiem spalinowym tłokowym - Zespoły prądotwórcze
Leszek Jarzębowicz, DEng. - doctor in the Faculty of Electrical and Control Engineering at Gdansk University of Technology.

Dr inż. Leszek Jarzębowicz - adiunkt na Wydziale Elektrotechniki i Automatyki Politechniki Gdańskiej.

e-mail:L.Jarzebowicz@ely.pg.gda.pl
[6] PN-ISO 8528-6:1997 Zespoły prądotwórcze prądu przemiennego napędzane silnikiem spalinowym tłokowym - Metody badań.

[7] Praca zbiorowa: Niepewność pomiarów w teorii i praktyce. Wydawnictwo GUM, Warszawa 2011.

[8] Skubis T.: Opracowanie wyników pomiarów, przykłady. Wydawnictwo Politechniki Śląskiej, Gliwice 2003.

[9] Taylor J.R.: Wstęp do analizy błędu pomiarowego. PWN, Warszawa 2011

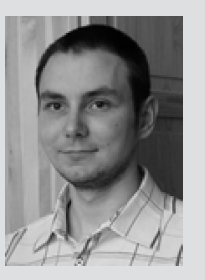

Jacek Skibicki, DEng. - doctor in the Faculty of Electrical and Control Engineering at Gdansk University of Technology.

Dr inż. Jacek Skibicki - adiunkt na Wydziale Elektrotechniki i Automatyki Politechniki Gdańskiej. e-mail: J.Skibicki@ely.pg.gda.pl

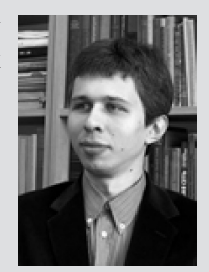

